\title{
FORMULASI BISKUIT BERBASIS TEPUNG JAGUNG SEBAGAI ALTERNATIF CAMILAN BERGIZI
}

\author{
Ade Irferamuna ${ }^{1}$, Asmar Yulastri $^{2}$, Yuliana $^{3}$ \\ ${ }^{1,2,3}$ Pascasarjana Pendidikan Teknik dan Kejuruan, Fakultas Teknik \\ Universitas Negeri Padang \\ e-mail: adeirferamuna@gmail.com, asmar11@gmail.com, yuliana56@gmail.com
}

\begin{abstract}
Abstrak
Konsumsi camilan sehat dapat menyediakan energi ekstra untuk beraktivitas dan membantu mencukupi kebutuhan energi sampai tiba waktu makan utama. Bahan dasar dari biskuit biasanya adalah tepung terigu. Mengurangi tingkat konsumsi tepung terigu, dapat dilakukan dengan cara mengganti sebagian tepung terigu (substitusi) dengan bahan pangan lokal yaitu tepung jagung. Penelitian ini bertujuan untuk mengembangkan formula biskuit siap-santap yang mengandung protein tinggi dan rendah lemak. Dikembangkan empat jenis formula biskuit dengan substitusi tepung jagung yaitu sebanyak $0 \%, 50 \%, 60 \%$ dan $70 \%$. Lalu biskuit diuji hingga valid dengan berdasarkan uji organoleptik oleh panelis ahli. Pengembangan formula yang valid menurut validator adalah formula dengan substitusi tepung jagung $70 \%$. Formula $70 \%$ diuji laboratorium memiliki kandungan kadar air 3,67\%, protein $4,31 \%$, dan lemak total $51,40 \%$. Formula terbaik adalah B4 (70\%). Formula ini cocok untuk dijadikan camilan alternatif bernutrisi.
\end{abstract}

Kata kunci : Tepung Jagung; Biskuit; Snack; Snack Bergizi

\begin{abstract}
Consumption of healthy snacks can provide extra energy for activities and help meet energy needs until the main mealtime. The basic ingredient of biscuits is usually flour. Reducing the level of consumption of wheat flour can be done by replacing some of the flour (substitution) with local food ingredients namely corn flour. This study aims to develop a ready-to-eat biscuit formula containing high protein and low fat. Four types of biscuit formula were developed with cornflour substitution, namely $0 \%, 50 \%, 60 \%$, and $70 \%$. Then the biscuits are tested until valid based on organoleptic testing by expert panelists. Development of a valid formula according to the validator is a formula with $70 \%$ corn flour substitution. Formula $70 \%$ of laboratory tested has a moisture content of $3.67 \%$, protein $4.31 \%$, and total fat $51.40 \%$. The best formula is B4 (70\%). This formula is suitable as an alternative nutritious snack.
\end{abstract}

Keywords : Corn Flour; Biscuit; Snack; Nutritious Snack 


\section{PENDAHULUAN}

Kemajuan zaman yang semakin pesat telah berdampak pada perubahan gaya hidup masyarakat Indonesia, mulai dari pola makan yang tidak sehat sampai kurangnya aktivitas fisik. Salah satunya kebiasaan mengonsumsi jajanan dan camilan yang tinggi lemak dan rendah serat namun tidak diimbangi dengan aktivitas yang cukup. Kebiasaan ini terutama terjadi pada masyarakat yang tinggal di perkotaan. Mereka lebih memilih untuk mengonsumsi makanan yang cepat dan praktis, seperti makanan cepat saji yang sebagian besar merupakan pangan hewani. Seringnya mengonsumsi pangan hewani yang tidak diimbangi dengan pangan nabati membuat asupan serat seseorang menjadi rendah. Hal ini dapat menyebabkan timbulnya berbagai penyakit degeneratif misalnya diabetes mellitus, jantung koroner, kolesterol, dan hipertensi [1]. Bekatul jagung dengan keunggulannya yang memiliki kadar serat yang tinggi (9.80\%) [2] maka bahan tersebut dapat dimanfaatkan untuk beberapa proses perbaikan gizi dimana salah satunya adalah untuk pembuatan biskuit. Biskuit bekatul jagung lebih dikhususkan untuk orang-orang dewasa serta lansia karena keberadaan serat yang tinggi tersebut $(9.80 \%)$ dapat menjaga dan meningkatkan fungsi saluran cerna serta dapat menjaga kesehatan tubuh, terutama dalam upaya menghindari penyakit degeneratif, seperti obesitas, diabetes militus, jantung koroner, kolesterol dan hipertensi [3]. Pada penelitian ini dilakukan pembuatan biskuit tinggi serat yaitu dengan menggunakan tepung bekatul jagung. Biskuit merupakan salah satu makanan ringan atau snack yang renyah yang banyak dikonsumsi oleh masyarakat [4]. Produk ini merupakan produk kering yang memiliki kadar air rendah, berdasarkan data asosiasi industri, tahun 2012 konsumsi biskuit diperkirakan meningkat $5 \%$ $8 \%$ didorong oleh kenaikan konsumsi domestik. Biskuit dikonsumsi oleh seluruh kalangan usia, baik bayi hingga kalangan dewasa tetapi dengan jenis yang berbedabeda. Namun, biskuit komersial yang beredar di pasaran memiliki kandungan gizi yang kurang seimbang. Kebanyakan biskuit memiliki kandungan karbohidrat dan lemak yang tinggi, sedangkan kandungan serat yang relatif rendah [5]. Untuk itu disini peneliti membuat biskuit tinggi serat (Setyowati, 2014).

Biskuit adalah produk yang diperoleh dengan memanggang adonan yang berasal dari tepung terigu dengan penambahan makanan lain dan dengan atau penambahan bahan tambahan pangan yang diijinkan.
Biskuit diklasifikasikan dalam empat jenis yaitu biskuit keras, crackers, cookies dan wafer (Badan Standardisasi Nasional, 2011). Data asosiasi tahun 2012 konsumsi biskuit diperkirakan meningkat 55-85\% didorong oleh kenaikan konsumsi domestik. Biskuit dikonsumsi oleh seluruh kalangan usia, baik bayi maupun dewasa mengkonsumsi biskuit dengan jenis yang berbedabeda (Sari, 2013). Senyawa antioksidan selain antosianin yang terdapat pada ubi jalar adalah vitamin C, vitamin $E$, lutein, zeaxanthin, dan betakaroten yang merupakan pasangan antioksidan karotenoid (Teow dkk (2007) dalam Husna dkk, 2013). Dari semua varietas warna umbi ubi jalar yang terdiri dari warna putih, kuning, oranye dan ungu. Hasil penelitian analisis vitamin $\mathrm{C}$ pada varietas ubi jalar yang umbinya berwarna ungu memiliki kandungan vitamin $\mathrm{C}$ paling besar yaitu $0,0177 \mathrm{mg} / 100$ gram (Syarfaini, 2017).

Camilan atau snack merupakan makanan ringan yang dikonsumsi diantara waktu makan utama. Umumnya camilan dikonsumsi kurang lebih 2-3 jam diantara waktu makan utama, yaitu pada pukul 10 pagi dan pukul 4 sore. Konsumsi camilan sehat dapat menyediakan energi ekstra untuk beraktivitas dan membantu mencukupi kebutuhan energi sampai tiba waktu makan utama. Rai, Bhole Shankar et al (2017) biskuit adalah produk panggang yang penting dalam makanan manusia dan biasanya dimakan bersama teh dan juga menyapih makanan untuk bayi. Mayoritas produk roti tinggi karbohidrat, lemak, dan kalori, tetapi kandungan seratnya rendah (Mishra \& Chandra, 2012).

Konsumsi makanan ringan sereal, seperti biskuit, kue, wafer, dan shortbread, telah menjadi sangat populer di Nigeria, terutama di kalangan anak-anak (Abayomi et al, 2013). Asosiasi Industri mendata pada tahun 2012 di perkirakan konsumsi biskuit meningkat $55,8 \%$ - $85 \%$ yang didorong oleh kenaikan konsumsi domestik. Peningkatan permintaan konsumen untuk produk makanan berkualitas dalam hal ini nutrisi, keamanan, kenyamanan dan rasa (Masoodi, L. et al., 2012).

Rai, Bhole Shankar et al (2017) tepung gandum merupakan bahan dasar untuk biskuit. Biskuit yang biasa dinikmati oleh masyarakat adalah biskuit yang berbahan baku tepung terigu, sedangkan terigu saat ini masih merupakan bahan pangan impor. Menginovasi biskuit dengan menambahkan ataupun menggantikan sebagian bahan makanan dengan bahan pangan lokal, akan 
memperkaya zat gizi yang terkandung dalam biskuit tersebut. Salahsatunya dengan penambahan tepung jagung sebagai pengganti sebagian tepung terigu. Omran, Azza A, et al (2016) komposisi terdekat sampel biskuit secara signifikan dipengaruhi oleh peningkatan rasio substitusi.

Gwirtz, Jeffrey. Jagung et al (2014) adalah sereal dengan produksi tertinggi di dunia dan digunakan untuk konsumsi manusia, pakan ternak, dan bahan bakar. Tepung jagung mengandung serat yang tinggi. Kandungan serat tepung jagung adalah 4,24\% dari 100 gram tepung jagung (Ambarsari, 2015). Istinganah, Miftakhul et al (2017) melakukan melakukan penelitian biskuit dengan formulasi perbandingan tepung jagung dengan tepung terigu 40:60, 60:40, dan 80:20, dan 100:0. Penelitian ini dilakukan dengan mengukur daya serap air dari perlakuan campuran tepung jagung dan tepung terigu. Hasil uji kekerasan menunjukkan terdapat pengaruh variasi campuran tepung jagung, tepung terigu dan volume air, dengan nilai $p=$ 0,042, dan perbandingan 80:20 memiliki tingkat kesukaan yang tertinggi.

Gwirtz, Jeffrey.et al (2014), jagung adalah sereal dengan produksi tertinggi di dunia dan digunakan untuk konsumsi manusia, pakan ternak, dan bahan bakar. Tepung jagung mengandung serat tinggi. Kandungan serat tepung jagung adalah 4,24\% dari 100 gram tepung jagung (Ambarsari, 2015). Istinganah, Miftakhul et al (2017) melakukan penelitian biskuit dengan formulasi perbandingan tepung jagung dengan tepung gandum 40:60, 60:40, dan 80:20, dan 100: 0 . Penelitian ini dilakukan dengan mengukur penyerapan air dari campuran tepung jagung dan tepung. Hasil uji kekerasan menunjukkan bahwa terdapat variasi campuran tepung jagung, tepung dan volume air, dengan nilai $p$ $=0,042$, dan rasio 80:20 memiliki tingkat preferensi tertinggi.

Sari, Retno Mekar (2017), melakukan penelitian dengan penambahan tepung jagung sebesar 50\%, 75\%, dan 100\% serta menggunakan kuning telur $30 \%$ dan $40 \%$. Formula biskuit terbaik penambahan tepung jagung $100 \%$ dan konsentrasi kuning telur $30 \%$. Penelitian ini bertujuan untuk mengembangkan formula biskuit siap-santap dengan substitusi tepung jagung.

\section{METODE}

Dikembangkan empat jenis formula biskuit dengan substitusi tepung jagung yaitu sebanyak 0\%, 50\%, 60\% dan 70\% (Tabel 1 ). Biskuit diuji hingga valid dengan berdasarkan uji organoleptik oleh panelis terbatas.

Tabel 1. Komposisi Formula Biskuit Tepung Jagung

\begin{tabular}{lcccc}
\hline \multirow{2}{*}{ Komposisi } & \multicolumn{4}{c}{ Formula (gr) } \\
\cline { 2 - 5 } & B 1 (0\%) & B 2 (50\%) & B 3 (60\%) & B 4 (70\%) \\
\hline Tepung Terigu (Low Protein) & 150 & 75 & 60 & 45 \\
Tepung Gula & 50 & 50 & 50 & 50 \\
Kuning Telur & 30 & 30 & 30 & 30 \\
Margarin & 100 & 100 & 100 & 100 \\
Susu Bubuk & 15 & 15 & 15 & 15 \\
Garam & 0,5 & 0,5 & 0,5 & 0,5 \\
Tepung Jagung & - & 75 & 90 & 105 \\
\hline
\end{tabular}

Bahan makanan untuk formula yang digunakan adalah: tepung terigu low protein (terigu cap kunci biru), margarin (blueband), tepung gula susu bubuk, garam, kuning telur, dan tepung jagung (Tabel 1) (Manley, 2001). Menghomogenkan mentega, kuning telur, garam, dan tepung gula selama 2 menit. Jauharah, M.Z Anis et al (2014) telur ditambahkan dan pencampuran dilanjutkan selama 2 menit. Setelah itu masukkan tepung terigu, susu bubuk, dan tepung jagung yang telah di ayak, aduk hingga tercampur dengan rata. Cetak adonan dengan menggunakan cetakan dengan ketebalan $0,5 \mathrm{~cm}$. Oven adonan dengan suhu $170^{\circ} \mathrm{C}$ dengan waktu kurang lebih 15 menit

Produk biskuit selanjutnya diuji deskriptif dan uji deskriminatif. Uji mutu organoleptik dan uji validitas formula biskuit, menggunakan angket untuk menilai skala atribut mutu organoleptik produk biskuit untuk mengetahui karakteristik atribut mutu penampakan warna, bentuk seragam, bentuk rapi, aroma jagung, tekstur, rasa gurih dan rasa jagung. Parameter skor adalah penampilan umum, bau, tekstur, dan rasa, menggunakan nilai maksimum 9 poin untuk setiap atribut sensorik sesuai dengan metodologi yang diusulkan (Gutkoski et al, 2007). 
Serta menguji validitas formula dari biskuit, sehingga ditemukan satu formula yang dipilih sesuai dengan rangking tertinggi setelah dinilai validitasnya oleh ahli. Penilaian ini akan dilakukan oleh para ahli pengembangan produk makanan yakni empat (4) orang dosen Tata Boga IKK FPP UNP dan satu (1) orang dari Bogasari Baking Center yang telah memiliki pendidikan dan pengalaman dalam pengembangan produk makanan. Skala uji organoleptik 1-5 (contoh,1 = tidak terasa jagung, 2 = kurang terasa jagung, 3 = cukup terasa jagung, 4 = terasa jagung, 5 = sangat terasa jagung).

Analisis data dilakukan melalui rata-rata skor dari atribut uji organoleptik, serta untuk uji deskriminatif dilakukan analisis data dengan Friedman test

$$
T=\left(\frac{12 \sum \sum R^{2}}{P t(t+1)}\right)-[3 p(t+1)]
$$

\section{HASIL DAN PEMBAHASAN}

Hasil uji deskriptif di dapatkan dari uji organoleptik, sesuai dengan mutu biskuit yang akan diinginkan (Tabel 1).

\section{Bentuk seragam}

Dari analisis diskriptif uji sensori atribut mutu bentuk seragam subsitusi $70 \%$ memiliki skor rata-rata paling baik yaitu 4,40, sedangkan formula kontrol $(0 \%)$ memiliki skor 4,33. Penggunaan bahan-bahan seperti margarin, dan tepung terigu dengan kadar protein yang sedang, dapat membantu dalam pembentukan adonan. Adonan yang dihasilkan tidak terlalu keras dan juga tidak terlalu lunak. Sehingga mudah untuk dicetak atau dibentuk

\section{Bentuk rapi}

Dari analisis diskriptif uji sensori atribut mutu bentuk rapi subsitusi $70 \%$ memiliki skor rata-rata paling baik yaitu 4,40 , sedangkan formula (0\%) memiliki skor 4,20.

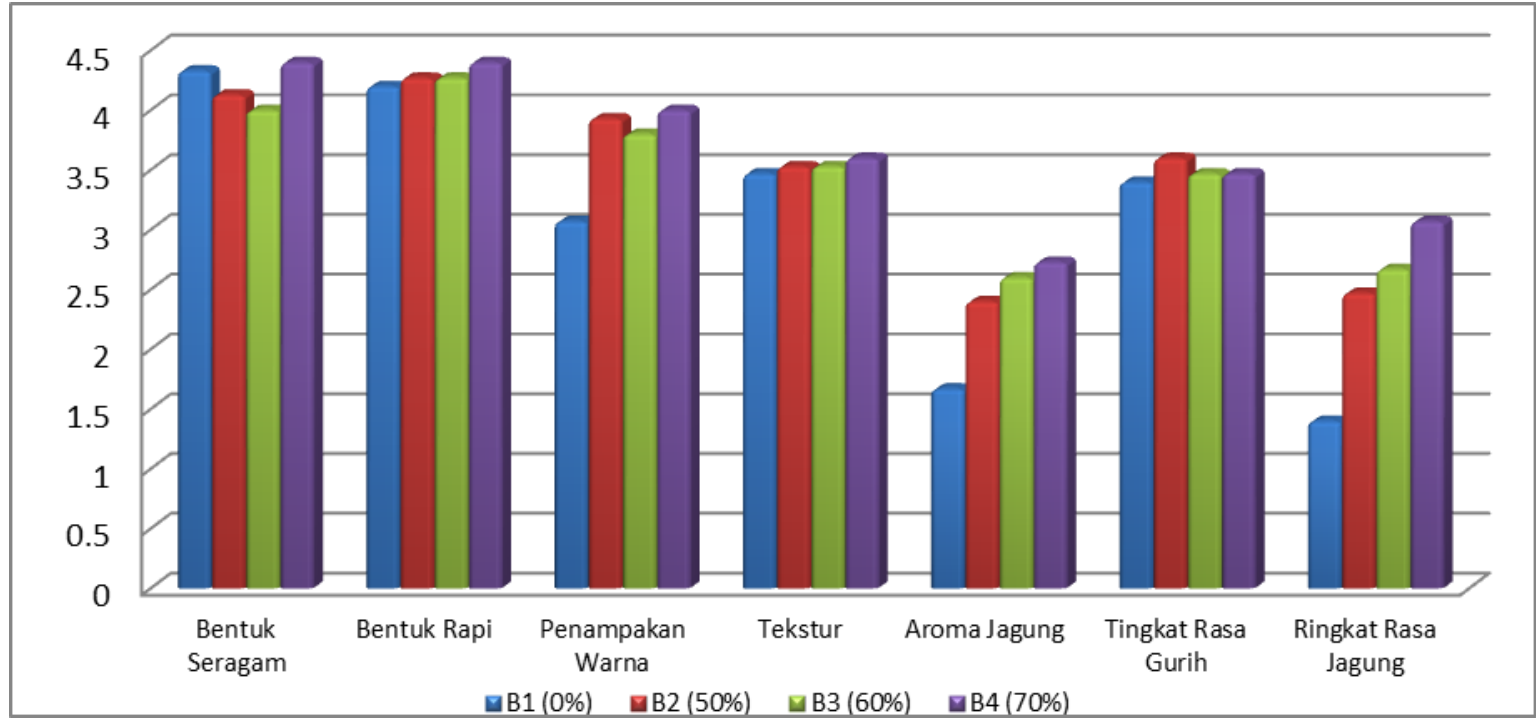

Gambar 1. Rata-rata Skor Uji Deskriptif

\section{Tekstur}

Dari analisis diskriptif uji sensori atribut mutu tekstur subsitusi $70 \%$ memiliki skor ratarata paling baik yaitu 3,60, sedangkan formula $(0 \%)$ memiliki skor 3,47. Semakin banyak substitusi tepung jagung dengan tepung terigu akan mengurangi tingkat kekerasan dari biskuit dan semakin mudah dipatahkan. Hal ini juga disebutkan dalam penelitian Istinganah, Miftakhul, et al (2017) bahwa secara statistik, hasil peneitian menunjukkan terdapat pengaruh pada variasi campuran tepung jagung dan tepung terigu terhadap kekerasan biskuit, dengan nilai $p=0,04 \quad(<0,05)$. Kekuatan maksimum yang diperlukan untuk memecahkan biskuit diukur seperti yang dijelaskan (Gaines, C.S, 1991).

\section{Aroma jagung}

Dari analisis diskriptif uji sensori atribut mutu aroma jagung subsitusi $70 \%$ memiliki skor rata-rata paling baik yaitu 2,73, sedangkan formula $50 \%$ memiiki skor 2,40 . Penggunaan tepung jagung dengan jumlah 
banyak akan meningkatkan aroma jagung pada produk biskuit. Aroma biskuit akan dihasilkan selama proses pemanggangan. Pada hasil penelitian Suarni (2009) terlihat persentase substitusi tepung jagung terhadap terigu akan mempengaruhi aroma produk.

\section{Rasa gurih}

Berdasarkan analisis diskriptif uji sensori atribut mutu tingkat rasa gurih subsitusi $50 \%$ paling baik dengan skor rata-rata 3,60. Rasa pada biskuit dipengaruhi oleh komposisi bahan lain yang seperti margarin yang mampu memperbaiki cita rasa pada biskuit, dan juga adanya protein yang terkandung pada tepung jagung dan tepung terigu dapat menimbulkan reaksi Maillard pada suatu bahan pangan (Murtiningsih, 2013).

\section{Rasa jagung}

Berdasarkan analisis diskriptif uji sensori atribut mutu tingkat rasa jagung subsitusi $70 \%$ paling baik dengan skor rata-rata 3,07. Hal ini terjadi karena, semakin banyak penambahan tepung jagung maka semakin terasa jagung. Istinganah, Miftakhul et al (2017), dalam hasil penelitiannya menunjukkan uji statistik menunjukkan bahwa terdapat pengaruh variasi campuran tepung jagung dantepung terigu dengan volume air yang proporsional, dengan nilai $p=0,005$.

\section{Uji Deskriminatif}

Pada uji deskriminatif, yang pertama dilakukan adalah analisis data dengan Friedman. Berdasarkan tabel output Test Statistics diatas, diketahui nilai Chi-Square sebesar 3,846. Karena nilai Chi-Square hitung 3,846 > Chi-Square tabel 0,05 maka, terdapat perbedaan rata-rata pada mutu biskuit (Tabel 2).

Tabel 2. Hasil Friedman Test

\begin{tabular}{cc}
\hline $\mathrm{N}$ & 5 \\
\hline Chi-Square & 3,846 \\
$\mathrm{df}$ & 2 \\
Asymp. Sig. &, 146 \\
\hline
\end{tabular}

Pada uji ranking, mean rank dari formula B 4 sebesar 2,50 menjadi urutan pertama, formula B 3 sebesar 2,00 menjadi urutan ke dua, dan formula B2 sebesar 1,50 menjadi urutan ke tiga. Dapat disimpulkan bahwa formula yang terbaik adalah formula B4 dengan substitusi tepung jagung dengan tepung terigu 70:30 (Tabel 3).

Tabel 3. Uji Rangking

\begin{tabular}{ll}
\hline B_2 & 1,50 \\
\hline B_3 & 2,00 \\
B_4 & 2,50 \\
\hline
\end{tabular}

\section{PENUTUP}

Subsitusi $70 \%$ memiliki bentuk seragam paling baik, subsitusi $70 \%$ memiliki bentuk rapi paling baik, subsitusi $50 \%$ memiliki penampakan warna paling baik, subsitusi $50 \%$ memiliki tekstur paling baik, subsitusi $70 \%$ memiliki tingkat aroma jagung paling baik, subsitusi $50 \%$ memiliki tingkat rasa gurih paling baik, dan subsitusi $70 \%$ memiliki tingkat rasa jagung paling baik dibandingkan dengan formula lainnya. Formula yang terbaik adalah B4 dengan substitusi tepung jagung dengan tepung terigu 70:30. Produk biskuit berbasis tepung jagung dinyatakan valid setelah dilakukan tiga kali uji organoleptik

\section{DAFTAR PUSTAKA}

Ambarsari, I. 2005. Pembuatan Tepung Jagung. Jawa Tengah. BPTP Jawa Tengah

Abayomi, H. T., et al. 2013. Quality evaluation of cookies produced from blends of sweet potato and fermented soybean flour. World Academy of Science, Engineering and Technology. International Journal of Biological, Food, Veterinary and Agricultural Engineering, 7, 350-355. 
Gaines, C.S. 1991. Instrumental measurement of the hardness of cookies and crackers. Cereal Foods World 36: 989-996

Gutkoski, L. C. et al. 2007. Biscoitos De Aveia Tipo Cookie Enriquecidos Com Concentrado De B-Glicanas. Brazilian Journal Of Food Technology V. 10, N. 2, P. 104-110.

Gwirtz, Jeffrey.A et al. 2014. Processing maize flour and corn meal food products. Annals Of The New York Academy Of Sciences Sci. 1312 (2014) 66-75

Jauharah, M.Z Anis et al (2014). Physicochemical and Sensorial Evaluation of Biscuit and Muffin Incorporated with Young Corn Powder. Sains Malaysiana 43(1)(2014): 45-52.

Istinganah, Miftakhul, et al. 2017. Tingkat kekerasan dan daya terima biskuit dari campuran tepung jagung dan tepung terigu dengan volume air yang proposional. Jurnal Kesehatan, Issn 1979-7621, Vol. 10, No. 2 p 83-93.

Manley, D. 2001. Biscuit, Cracker, And Cookie Recipes For The Food Industry. Woodhead Publishing Limited. Cambridge

Masoodi L, Bashir VAK. 2012. Fortification of Biscuit with Flaxseed: Biscuit Production and Quality Evaluation. Journal of Environmental Science, Toxicology And Food Technology, 2012

Mishra, N. \& Chandra, R. 2012. Development of functional biscuit from soy flour \& rice bran. International Journal of Agricultural and Food Science 2: 14-20

Murtiningsih. 2013. Kajian Kualitas Biskuit Jagung. J. Rekapangan Vol. 7 No. 1 2013 p 111-122.
Rai, Bhole Shankar, Et Al. 2017. Quality Characteristics of Biscuits produced from composite flour of wheat, maize and sesame seed. Journal of Pharmacognosy and Phytochemistry 2017; 6(4): 2011-2015

Sari, Retno Mekar. 2017. Pengaruh Penambahan Tepung Jagung (Zea Mays) dan Kuning Terhadap Sifat Fisik, Kimia dan Organoleptik Biskuit. Universitas Sriwijaya. Sumatera Selatan.

Setyowati, Weny Tri. 2014. Formulasi Biskuit Tinggi Serat (Kajian Proporsi Bekatul Jagung : Tepung Terigu Dan Penambahan Baking Powder). Jurnal Pangan dan Agroindustri Vol. 2 No 3 p.224-231, Juli 2014

Syarfaini. 2017. Analisis Kandungan Zat Gizi Biskuit Ubi Jalar Ungu (Ipomoea Batatas L. Poiret) Sebagai Alternatif Perbaikan Gizi Di Masyarakat. Jurnal Universitas Islam Negeri Alauddin Makassar Volume 9, Nomor 2, Juli-Desember 2017

Suarni. 2009. Prospek Pemanfaatan Tepung Jagung Untuk Kue Kering (Cookies). Jurnal Litbang Pertanian, 28(2) p. 63-71. 